\title{
Plasmid profile and drug resistance pattern of zoonotic Salmonella isolates from Indian buffaloes
}

\author{
Bhoj R Singh, Meenu Agarwal, Mudit Chandra, Meena Verma, Gautam Sharma, Jagdish C \\ Verma and Vijay P Singh
}

National Salmonella Centre (Vet), Division of Bacteriology and Mycology, Indian Veterinary Research Institute, Izatnagar-243 122 India

\begin{abstract}
Background: Buffalo is the major source of animal protein in south-east Asia, including India; therefore, the presence of multiple drug resistance in Salmonella strains of buffalo meat and milk products is of immense public health concern.

Methodology: Forty-six strains of Salmonella enterica subspecies enterica belonging to eight serovars $(S$. Anatum, 13; $S$. Weltevreden, 13; $S$. Rostock, 6; $S$. Typhimurium, 5; $S$. Gallinarum, 5; $S$. Stockholm, 1; $S$. Dublin, 1; and $S$. Orion, 2), isolated from buffalo meat and diseased buffaloes were studied for their antibiotic sensitivity and plasmid profile.

Results: All except six strains of Salmonella had one or more plasmids. Virulence plasmid of $\sim 35 \mathrm{MdA}$ was present in 39 isolates while 19 strains had one to six additional plasmids with molecular weight ranging from 1 Mda $>35 \mathrm{Mda}$. A plasmid-free $S$. Anatum strain was resistant to seven drugs including fluoroquinolones, while strains having six to seven plasmids were resistant to fewer antimicrobial drugs. One $S$. Anatum isolate, resistant to 11 antibiotics, had only one plasmid. Eight serovars of Salmonella could be divided into 28 resistotypes on the basis of antimicrobial sensitivity assay. Most strains were resistant to streptomycin (84.8\%) followed by kanamycin (58.7\%), gentamicin $(52.2 \%)$, ampicillin $(50 \%)$ and oxytetracycline $(50 \%)$. Few strains were resistant to cefotaxime $(2.2 \%)$, amoxycillin $(2.2 \%)$ and newer fluoroquinolones $(6.5 \%)$.

Conclusion: Multiple drug resistance was common among Salmonella isolates of buffalo origin, particularly against aminoglycosides, oxytetracycin, ampicillin and cephalexin. Presence of plasmids is not mandatory for occurrence of multiple drug resistance in $S$. enterica strains.
\end{abstract}

Key words: buffaloes, Salmonella enterica, Typhimurium, Weltevreden, MDR, plasmids

J Infect Dev Ctries 2010; 4(8):477-483.

(Received 29 November 2009 - Accepted 16 April 2010)

Copyright (C) 2010 Singh et al. This is an open-access article distributed under the Creative Commons Attribution License, which permits unrestricted use, distribution, and reproduction in any medium, provided the original work is properly cited.

\section{Introduction}

Buffalo farming is a major contributor to the agriculture and livestock industry in many Asian countries through the production of good quality milk, meat and farmyard manure [1]. Therefore, the pathogens either causing disease in buffaloes and their progeny or transmitted through their produce are important because they affect milk production and overall livestock production. In buffaloes, Salmonella is both a major pathogen causing calf diarrhoea [2-6] leading to early-age calf-mortality [7-9] and a foremost pathogen transmitted through animal products. More than $10 \%$ of buffalo meat samples have been reported as contaminated with Salmonella in northern India [10]. Antibiotics are generally used as growth-promoting substances for livestock in the developing world. After the use of growth antibiotics in animals, S. enterica serovar Weltevreden emerged as the most common Salmonella serovar globally [11], and is reported to constitute more than $20 \%$ of Salmonella isolates of buffalo origin in India [12]. Salmonella Weltevreden has not only emerged in animals in India, but also in humans, and more than $29 \%$ of Salmonella isolates of human origin belonged to single serovar [13]. Some other commonly reported Salmonella serovars in buffaloes include $S$. Typhimurium, $S$. Dublin, $S$. Chester, $S$. Bareilly, $S$. Lagos, S. Orion, S. Saintpaul, S. Stanley, S.I. 4,12:i:-, S.I. 3,10:r:- and rough non-typable strains [12,14-16].

While buffalo have long been identified as a source of Salmonella, little is known about multidrug-resistance (MDR) and plasmids of Salmonella isolates of buffaloes; therefore, this study was undertaken to determine antimicrobial drug sensitivity and plasmid profiles of Salmonella strains 
of buffalo origin to gain a better understanding of salmonellae of buffaloes.

\section{Materials and Methods}

Salmonella strains

All 46 strains of Salmonella enterica subspecies enterica isolated from buffalo meat and diseased buffaloes in India (during 2002-2005), belonging to eight serovars (namely, $S$. Anatum, 13; $S$. Weltevreden, 13; $S$. Rostock, 6; $S$. Typhimurium, 5; $S$. Gallinarum, 5; $S$. Orion, 2; $S$. Stockholm, 1; and $S$. Dublin, 1) were obtained from stocks from the National Salmonella Centre (Vet), Indian Veterinary Research Institute, Izatnagar, repository. All the strains were submitted from different veterinary institutions in India for serotyping to the National Salmonella Centre [12] with information about the source of isolation and date of isolation. As the isolates were always endorsed by the respective heads of microbiology departments, we never questioned the accuracy of the information provided with the strains. All isolates were revived and confirmed through biochemical and serological methods [17]. For serotyping, anti $\mathrm{O}$ and anti $\mathrm{H}$ group and factor-specific serum (Difco BBL, USA) were used to perform the standard tube agglutination test with $\mathrm{O}$ and $\mathrm{H}$ antigens prepared from each of the strains [17]. Except for $S$. Typhimurium (2), $S$. Weltevreden (13) and $S$. Stockholm (1), which were isolated from fresh buffalo meat samples, all other strains (30) were isolated from faecal samples of buffalo calves with clinical diarrhoea in the last three years [12].

\section{Plasmid profiling}

The method of Hames and Higgins [18] was followed for isolation of plasmids using bacteria pelleted from $10 \mathrm{ml}$ of overnight grown culture in Luria Bertani (LB) broth using the phenol:chloroform extraction method. Plasmid DNA was dissolved in 50 $\mu \mathrm{l}$ sterile distilled water containing $0.1 \mathrm{mg}$ RNase-A $\mathrm{ml}^{-1}$ and stored at $-20^{\circ} \mathrm{C}$. Plasmid preparations were electrophoresed on $0.7 \% \mathrm{w} / \mathrm{v}$ agarose (SRL, India) gel. The plasmid DNA bands were visualized and photographed under a UV-transilluminator and gel documentation system (UVP, England). The plasmid ladder used was extracted from the E. coli (E381) reference strain having 7 plasmids of $1.79 \mathrm{MDa}, 2.03$ MDa, 2.63 MDa, 3.39 MDa, 3.69 MDa, 5.19 MDa and $35.8 \mathrm{Mda}$.

\section{Antimicrobial sensitivity assay}

Antimicrobial sensitivity of all Salmonella isolates was determined in triplicate by the disc diffusion method [19] on Muller Hinton agar No. 4 against 16 antimicrobials belonging to seven classes namely, penicillins (ampicillin $10 \mu \mathrm{g}$, amoxycillin 10 $\mu \mathrm{g}$ ); chloramphenicol $30 \mu \mathrm{g}$; cephalosporins (cefotaxime $30 \mu \mathrm{g}$, cephalexin $30 \mu \mathrm{g}$ ); fluoroquinolones (ciprofloxacin $5 \mu \mathrm{g}$, enerofloxacin 5 $\mu \mathrm{g}$, lomefloxacin $2 \mu \mathrm{g}$, norfloxacin $30 \mu \mathrm{g}$ ); aminoglycosides (gentamicin $10 \mu \mathrm{g}$; kanamycin 30 $\mu \mathrm{g}$; streptomycin $10 \mu \mathrm{g})$; cotrimoxazole $25 \mu \mathrm{g}$; quinolone (nalidixic acid) $30 \mu \mathrm{g}$; nitrofurantoin 300 $\mu \mathrm{g}$; and oxy-tetracycline $30 \mu \mathrm{g}$ discs (Hi-media, Mumbai, India). Based on the zone of inhibition, isolates were classified as sensitive or resistant [19]. The strains resistant to three or more groups of drugs were classed as multi-drug-resistant (MDR) strains. A reference $E$. coli $\mathrm{K} 12$ strain (E-382), sensitive to all antimicrobials, was used as the control.

\section{Results}

All strains had one or more plasmid except five strains of $S$. Anatum and one each of $S$. Orion and $S$. Gallinarum; those had no plasmids including $~ 35$ MDa plasmids. All seven plasmid-free strains were isolated from buffalo calves with diarrhoea, while, all strains of buffalo meat (buffen) origin had one or more plasmid.

A comparatively heavier plasmid ( > 35.8 MDa) was also present in six strains, including two strains each of $S$. Anatum and $S$. Weltevreden and one strain each of $S$. Orion and $S$. Rostock. In addition to the -35 MDa plasmid, 1 Mda (3 strains), 2 Mda (3 strains), 3 Mda (2 strains), 5 Mda (1 strain), 8 Mda (1 strain) and 12 Mda (3 strains), plasmids were also detected in a number of strains. A comparatively heavier plasmid (molecular weight $>35.8 \mathrm{MDa}$ ) was also present in six strains, including two strains each of $S$. Anatum and $S$. Weltevreden and one strain each of $S$. Orion and $S$. Rostock.

Salmonella strains of buffalo origin were resistant to comparatively fewer antimicrobials (1-8 drugs) than those from calf diarrhoea (1-11 drugs). Salmonella Typhimurium and $S$. Stockholm from buffalo were resistant to tetracycline only; however, $S$. Weltevreden of buffalo origin were resistant to three to eight drugs. The majority of the Salmonella isolates from buffaloes were resistant to streptomycin (39), followed by kanamycin (27), gentamicin (24), ampicillin (23), oxytetracycline (23), cephalexin (19), 
Table. 1. Antimicrobial drug resistance pattern of Salmonella strains of buffalo origin

\begin{tabular}{|c|c|c|c|c|}
\hline$\overline{\text { S.No. }}$ & $\begin{array}{l}\text { Resistant to } \\
\text { No. of drugs }\end{array}$ & Drugs resisted (Number of strains) & Number of strains & $\begin{array}{l}\text { Number of group of drugs } \\
\text { resisted }\end{array}$ \\
\hline \multirow[t]{5}{*}{1} & \multirow[t]{5}{*}{1} & $\mathrm{Na}(1)$ & S. Rostock & 1 \\
\hline & & $\mathrm{T}(5)$ & S. Stockholm (1), & 1 \\
\hline & & & S. Gallinarum (2), & 1 \\
\hline & & & S. Typhimurium (2) & 1 \\
\hline & & S (2) & $S$. Rostock & 1 \\
\hline \multirow[t]{5}{*}{2} & \multirow[t]{5}{*}{3} & A, K, S (3) & S. Typhimurium & 2 \\
\hline & & $\mathrm{A}, \mathrm{Na}, \mathrm{S}(1)$ & S. Dublin & 3 \\
\hline & & $\mathrm{A}, \mathrm{Cp}, \mathrm{S}(2)$ & $S$. Rostock & 3 \\
\hline & & Nf, S, T (2) & S. Anatum & 3 \\
\hline & & $\mathrm{Na}, \mathrm{S}, \mathrm{T}(2)$ & $S$. Weltevreden & 3 \\
\hline 3 & 4 & $\mathrm{Cp}, \mathrm{Nf}, \mathrm{S}, \mathrm{T}(3)$ & $S$. Weltevreden & 4 \\
\hline \multirow[t]{6}{*}{4} & \multirow[t]{6}{*}{5} & $A, C, G, K, S(1)$ & $S$. Rostock & 4 \\
\hline & & $\mathrm{A}, \mathrm{G}, \mathrm{K}, \mathrm{S}, \mathrm{T}(1)$ & S. Anatum & 3 \\
\hline & & $\mathrm{A}, \mathrm{G}, \mathrm{K}, \mathrm{Nf}, \mathrm{S}(2)$ & $S$. Orion & 3 \\
\hline & & $\mathrm{G}, \mathrm{K}, \mathrm{Nf}, \mathrm{S}, \mathrm{T}(1)$ & S. Anatum & 3 \\
\hline & & A, Na, No, S, T (1) & $S$. Weltevreden & 5 \\
\hline & & $\mathrm{C}, \mathrm{Cp}, \mathrm{G}, \mathrm{K}, \mathrm{S}(3)$ & S. Gallinarum & 3 \\
\hline \multirow[t]{6}{*}{5} & \multirow[t]{6}{*}{6} & $\mathrm{~A}, \mathrm{G}, \mathrm{K}, \mathrm{No}, \mathrm{S}, \mathrm{T}$ (1) & S. Anatum & 4 \\
\hline & & $\mathrm{A}, \mathrm{C}, \mathrm{G}, \mathrm{K}, \mathrm{No}, \mathrm{S}(1)$ & $S$. Weltevreden & 4 \\
\hline & & $\mathrm{A}, \mathrm{Cp}, \mathrm{G}, \mathrm{K}, \mathrm{S}, \mathrm{T}(1)$ & S. Anatum & 4 \\
\hline & & $\mathrm{C}, \mathrm{Cp}, \mathrm{G}, \mathrm{K}, \mathrm{Nf}, \mathrm{S}(3)$ & $S$. Weltevreden & 4 \\
\hline & & $\mathrm{Cp}, \mathrm{G}, \mathrm{K}, \mathrm{Nf}, \mathrm{S}, \mathrm{T}(1)$ & S. Anatum & 4 \\
\hline & & $\mathrm{A}, \mathrm{Cp}, \mathrm{G}, \mathrm{K}, \mathrm{Nf}, \mathrm{S}(2)$ & $S$. Weltevreden & 4 \\
\hline 6 & 7 & $\mathrm{~A}, \mathrm{C}, \mathrm{G}, \mathrm{K}, \mathrm{Lo}, \mathrm{No}, \mathrm{Na}(1)$ & $S$. Anatum & 5 \\
\hline \multirow[t]{3}{*}{7} & \multirow[t]{3}{*}{8} & A, Cf, Cp, En, G, K, No, S (1) & S. Anatum & 4 \\
\hline & & A, Co, Cp, G, K, Nf, S, T (1) & S. Weltevreden & 6 \\
\hline & & A, C, Co, G, K, No, S, T (1) & S. Anatum & 6 \\
\hline \multirow[t]{2}{*}{8} & \multirow[t]{2}{*}{10} & $\mathrm{~A}, \mathrm{Cf}, \mathrm{Co}, \mathrm{En}, \mathrm{G}, \mathrm{K}, \mathrm{Na}, \mathrm{No}, \mathrm{S}, \mathrm{T}$ (1) & S. Anatum & 6 \\
\hline & & $\mathrm{A}, \mathrm{Ce}, \mathrm{Co}, \mathrm{Cp}, \mathrm{G}, \mathrm{K}, \mathrm{Na}, \mathrm{No}, \mathrm{S}, \mathrm{T}$ (1) & S. Anatum & 7 \\
\hline 9 & 11 & $\mathrm{~A}, \mathrm{Am}, \mathrm{Cf}, \mathrm{Co}, \mathrm{Cp}, \mathrm{G}, \mathrm{K}, \mathrm{Lo}, \mathrm{No}, \mathrm{S}, \mathrm{T}(1)$ & S. Anatum & 6 \\
\hline
\end{tabular}

nitrofurantoin (15), chloramphenicol (10), norfloxacin (8), nalidixic acid (6), cotrimoxazole (5), ciprofloxacin (3), enerofloxacin (2), lomefloxacin (2), amoxycillin (1), and cephotaxime (1).

Except eight strains resistant to only one group of antimicrobial drugs (1 to nalidixic acid, 2 to streptomycin, and 5 to oxytetracycline) and three strains that were resistant to two groups of antimicrobials, the remaining 35 strains were resistant to three to seven groups of antimicrobials (Table 1), and were named as multi-drug resistant
(MDR) strains. On the basis of their resistance patterns, strains of 8 serovars could be grouped into 28 resistance groups (resistotypes). All 26 strains of $S$. Weltevreden and $S$. Anatum were MDR (Table. 1). A plasmid-free strain of $S$. Anatum was resistant to seven drugs from five different groups, including fluoroquinolones, while three strains of $S$. Weltevreden that had six (2) or seven (1) plasmids were resistant to only three (2) or four (1) antimicrobial drugs. An isolate of $S$. Anatum resistant to 11 antibiotics had only one plasmid. Drug 
resistance was common among Salmonella against streptomycin, kanamycin, oxytetracycin, ampicillin, and cephalexin. The study indicated that the presence or number of plasmids is not associated with resistant phenotype in S. enterica strains of buffalo origin.
Except for S. Gallinarum, most of the Salmonella serovars studied were of known zoonotic potential. Salmonella Orion, $S$. Stockholm, $S$. Dublin, $S$. Typhimurium and $S$. Weltevereden strains have long been known to cause septicemia and foodborne

Figure 1. Plasmid profiles of strains of Salmonella enterica serovars isolated from buffaloes.

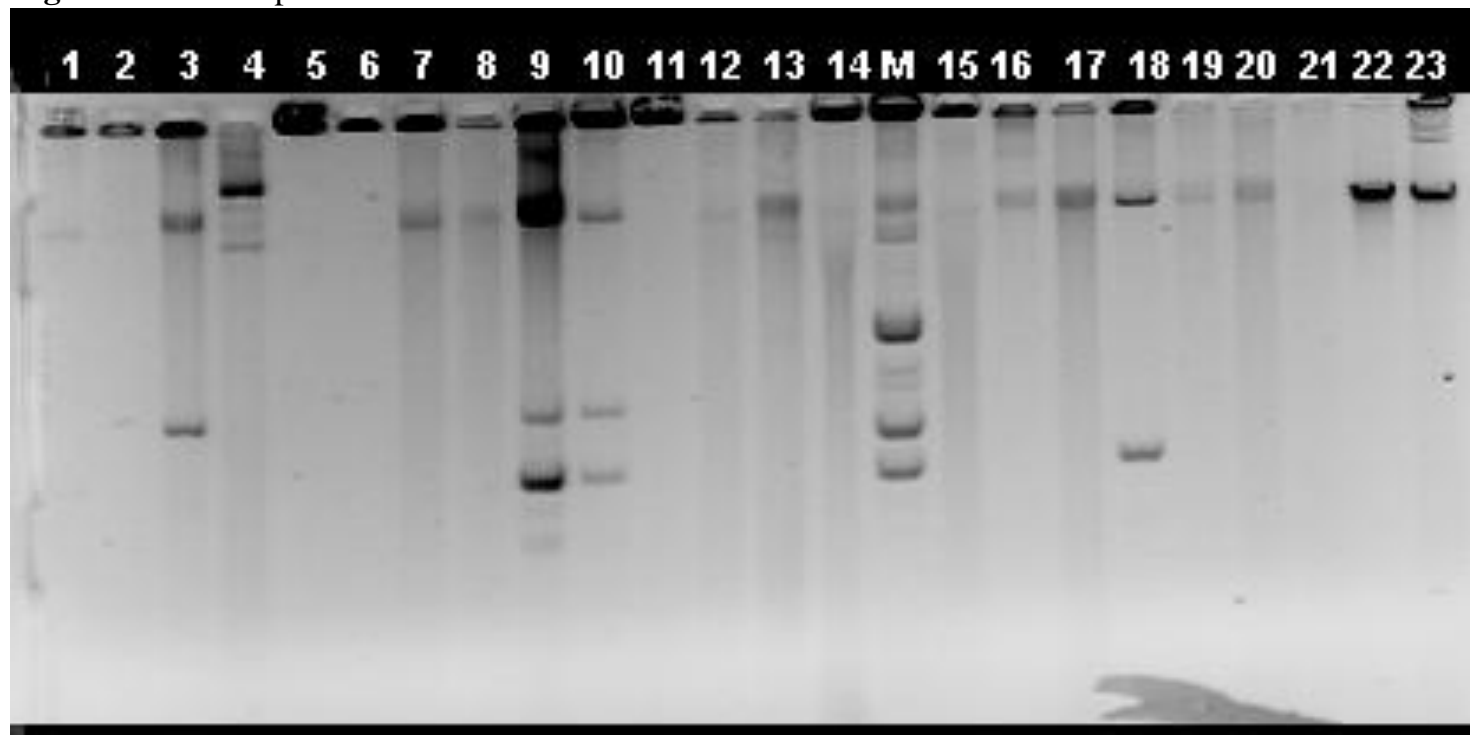

Electrophoresed on $0.7 \%$ agraose gel, lane $\mathrm{M}$ contains the preparation from reference strain containing 7 plasmids of molecular weight (1.79 MDa, 2.03 MDa, 2.63 MDa, 3.39 MDa, 3.69 MDa, 5.19 MDa and 35.8 Mda). In the remaining lanes numbered with Arabic numerals, plasmid preparation of S. Anatum (lanes 1-13), S. Rostock (lanes 14-19), S. Stockholm (lane 20), S. Orion (lanes 21,23) and S. Dublin (lane 22) were loaded.

\section{Discussion}

Although seven strains of Salmonella from buffaloes had no detectible virulence plasmid, including a heavy plasmid considered important for virulence in Salmonella, it can not be inferred that the strains were nonpathogenic because plasmids may either be atypical in size [20] or absent as previously reported in pathogenic $S$. Paratyphi B [21]. Furthermore, it is also possible that plasmid-free Salmonella strains might have virulence genes in the chromosome [22].

MDR Salmonella from buffalo calves and buffen are of public health importance because their zoonotic potential and ability to spread through contaminated buffalo products, direct contact, or through contamination of the environment with the excretions of sick buffaloes that can result in contaminated food and water. However, in India, there is no available report regarding the use of antimicrobial drugs in buffaloes. It is not feasible, therefore, to discuss the antimicrobial drug resistance pattern of salmonellae from buffaloes with relation to antimicrobial drug uses. illness in humans [13,23-28]. Although $S$. Anatum is primarily considered as a duck and waterfowl pathogen causing keel disease [29], it was one of the most common isolates from buffalo calves with diarrhoea and resistant to the most number of antimicrobials among all Salmonella isolates of buffalo origin under study. Salmonella Anatum, mostly a cause of enteritis, septicemia, and arthritis in ducklings, was first recognized to cause infection in human infants in 1948 [30]. Since then it has emerged as an important zoonotic pathogen and has caused widespread outbreaks. The most devastating international $S$. Anatum outbreak was associated with infant milk formula affecting many European countries, and the causative agent was resistant to ampicillin and sulphonamides [31]. In the current study, several strains of $\mathrm{S}$. Anatum were also resistant to ampicillin as well as sulphonamide (Cotrimoxazole).

Association of various MDR Salmonella serovars with buffalo calf diarrhoea might be expected as many of the Salmonella strains that commonly occur in India are MDR with similar resistance patterns, as 
observed in the present study [3,9,12]. However, strains of serovar $S$. Gallinarum and $S$. Anatum, the two serovars primarily adapted to birds [29], are of special significance as a cause of diarrhoea in buffalo calves, but their antibiotic resistance patterns are not much different from those isolated earlier in India from birds, animals, and human patients [32-33]. Observations indicated that even host adapted Salmonella serovars might have some other important host or niche in ecosystem. The observations concur with earlier reports of the isolation of $S$. Typhi, primarily a human host adapted serovar, from camels [12]. Thus further studies on so- chromosomes [21]. However, rapid spread and persistence of zoonotic salmonellosis in food animals and pet animals is associated with emerging multiple drug resistance often mediated by R-plasmids and plasmids having integrons carrying R-genes [27,36,37], but MDR strains without plasmids can not be considered less dangerous. In recent years, chromosomal genes responsible for the efflux mechanism are found to be a major cause of antimicrobial resistance in freshly isolated Salmonella strains, even in the absence of R-plasmid genes and integrons, and such strains might be associated with difficult-to-cure infections [26,34,

Figure 2. Plasmid profiles of strains of Salmonella enterica serovars isolated from buffaloes.

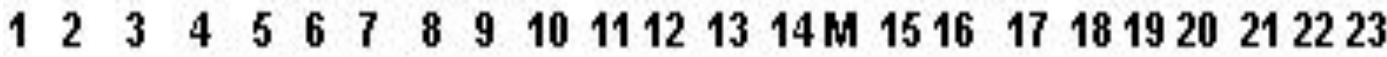

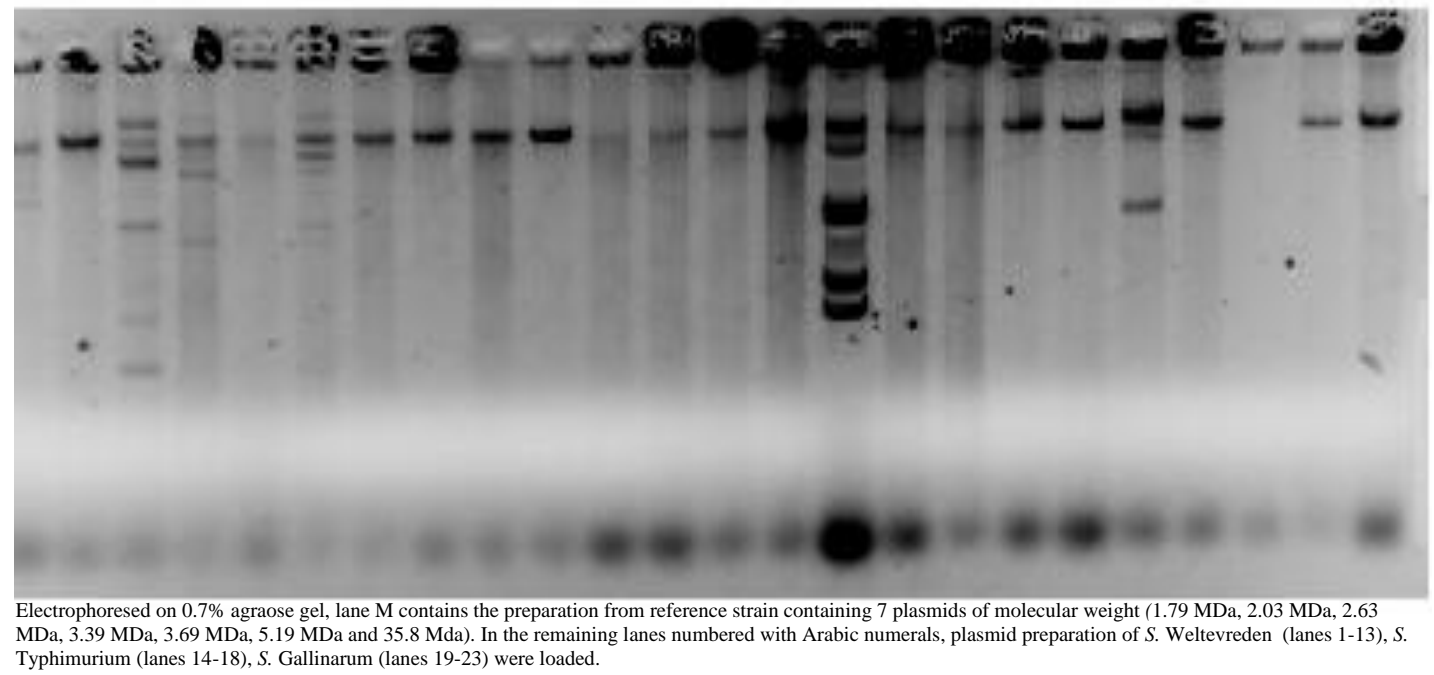

called host-adapted or host-restricted serovars may reveal the important patho-biomolecules associated with widening host adaptability in Salmonella.

Typical MDR resistance to streptomycin+ tetracycline+ chloramphenicol, common in India in human typhoid strains [26,34], was rare in Salmonella strains of buffalo origin and was detected only in one strain of $S$. Anatum. However, resistance to fluoroquinolones, though only in few strains, and resistance to nalidixic acid, are of public health concern because these are commonly used drugs for infectious diarrhoea, foodborne infections and nontyphoidal salmonellosis in humans [34] and animals [35].

Absence of a correlation between antimicrobial drug resistance and the presence of plasmids in isolates of Salmonella of buffalo origin might be due to the presence of drug resistance genes on
38]. Therefore, MDR strains of Salmonella of buffalo origin might be important for both public and personal health, as well as for epidemiologists monitoring the spread of MDR in zoonotic pathogens. Further studies on plasmid-free strains for MDR may also reveal the alternate strategy of bacteria to maintain $\mathrm{R}$ genes.

\section{References}

1. Dairy industry in India. (2007) http://www.indiaagronet.com/indiaagronet/DAIRY/dairy3.ht m. Viewed on 17 February 2009.

2. Amrousi SEL, Nafie EK, Rehewi MEL, Mottilib AA (1971) Studies on enteritis in buffalo calves in Assiut. J Egypt Vet Med Assoc 31: 219-225.

3. Joseph PG, Anwar M, Jegathesan M (1978) Animal Salmonellosis in Peninsular Malaysia. II. Annual and Zoological Distribution of Salmonella Serotypes over the 
10-Year Period 1966-1975. American J Trop Med Hyg 27: 562-566.

4. Bali MK, Juneja IJ, Khanna RNS (1979) A clinical note on buffalo calf mortality. Indian J Dairy Sci 32: 370-372.

5. Ismail M, Girgis SM, El-Jakee J, Shokry S, Riad EM (1990) Bacteriological studies on the diarrhhoea in newly born buffalo calves. Vet Med J Giza 38: 219-232.

6. Ribeiro MG, Langoni H, Jerez JA, Leite DS, Ferreira F, Gennari SM (2000) Identification of enteropathogens from buffalo calves with and without diarrhoea in the Ribeira Valley, State of São Paulo, Brazil. Brazilian J Vet Res Anim Sci 37: 172-178.

7. Verma PC, Kalra DS (1975) Studies on buffalo (Bos bubalis) calf mortality, with special reference to its aetiology. Indian Vet J 52: 605-609.

8. Lau HD (1987) Principais doenças dos bezerros búfalos lactentes no Estado do Pará. Boletim de Pesquisa EmbrapaCpatu 83: 5-12.

9. Kaura YK (1988) A two-year surveillance (1984-1986) on the incidence of Salmonella serotypes in diarrhoeic calves at some of the organized animals farms. Indian J Anim Sci 58: 1361-1368.

10. Sharma VD, Singh SP, Taku A, Dixit VP (1989) Salmonella in goat, sheep and buffalo meat: Occurrence and enterotoxigenicity. Indian $\mathrm{J}$ Comp Microbiol Immunol Infect Dis 10: 180-185

11. WHO (1997) The Medical Impact of Antimicrobial Use in Food Animals. Report of a WHO Meeting, Berlin, Germany, 13-17 October 1997. WHO/EMC/ZOO/97.4 pp. 4-21

12. Singh BR (2005) Prevalence of Salmonella serovars in animals in India. http://www.aclisassari.com/acliopenlearning/uploads/lectures/Methods. Viewed on 14 November 2007.

13. Basu S, Sood LR (1975) Salmonella weltevreden: a serotype of increasing public health importance in India. Trop Geogr Med 27: 387-394.

14. Gupta BR, Mataney CF (1968) Isolation of Salmonella organisms from buffalo calves. Indian Vet J 45: 629-633.

15. Gupta BR, Verma JC (1990) Prevalence of Salmonella in farms animals and birds in India. Indian J Comp Microbiol Immunol Infect Dis 11: 169-174.

16. Kumar AA, Mallick BB, Verma JC, Gupta BR (1981) Isolation of Salmonella (3,10: r:-) from animals and its public health importance. Indian J Med Res 73: 693-696.

17. Popoff MY, LeMinor L (2002) Antigenic formulas of the Salmonella serovars (WHO Collaborating Centre for Reference and Research on Salmonella), Institute Pasteur, 28 Ruc du Dr. Roux, 75724 Paris Cedex 15, France.

18. Hames BP, Higgins SJ (1995) Gene Probes I: A practical approach. Oxford University Press, Oxford.

19. Clinical and Laboratory Standards Institute (CLSI) (2006) Performance standards for antimicrobial disk susceptibility tests; Approved Standard, 9th Edition. Document M02-A9, and M100-S18- 17th Informational Supplement, Wayne.

20. Singh BR, Mark PS, Wallis T (1999) Characterization of Salmonella Abortusequi strains harbouring defined mutations, in $\operatorname{aro\mathrm {A}}, h t r \mathrm{~A}$, and double mutant (aroA-htrA) of $S$. Abortusequi, TOMBIT Report, Indian Council of Agricultural Research, New Delhi.

21. Agarwal M, Chandra M, Sharma G, Singh BR (2005) A Study on Virulence Markers of Indian Strains of Salmonella enterica subspecies enterica serovar Paratyphi B from Foods of Animal Origin. J Food Sci Technol 42: 66-79.
22. Fields PI, Groisman EA, Heffron F (1989) A Salmonella locus that control resistance to microbial protein from phagocytic cells. Sci 243: 1059-1062.

23. Agarwal RK, Kapoor KN, Verma JC, Bachhil VN, Singh BR, Kumar A, Sachan N, Singh DK, Malik SVS (1999) Isolation and characterization of Salmonella Stockholm from beef. Indian J Comp Microbiol Immunol Infect Dis 20: $50-52$.

24. Allerberger F, Liesegang A, Grif K, Khaschabi D, Prager R, Danzl J, Höck F, Öttl J, Dierich MP, Berghold C, Neckstaller I, Tschäpe H, Fisher I (2003) Occurrence of Salmonella enterica serovar Dublin in Austria. Wiener Med Wochenschrift 153: 148-152.

25. Cabrera R, Ruiz J, Ramírez M, Bravo L, Fernández A, Aadueña A, Echeíta A, Gascón J, Alonso PL, Vila J (2006) Dissemination of Salmonella enterica serotype agona and multidrug-resistant Salmonella enterica serotype Typhimurium in Cuba. Am J Trop Med Hyg 74: 1049-1053.

26. Vishwanathan R (2006) Current Anti-biogram of Salmonella Species Isolated from Blood. J Asso Physicians India 54: 666-667.

27. Threlfall EJ, Rowe B, Ward LR (1993) A comparison of multiple drug resistance in Salmonellas from humans and food animals in England and Wales 1981 and 1990. Epidemiol Infect 111: 189-197.

28. Small RG, Sharp JCM (1979) A Milk-Borne Outbreak Due to Salmonella dublin. The J Hyg 82: 95-100.

29. Edwards PR, Ewing WH (1972) Identification of Enterobacteriaceae. New York, Elsevier Science \& Burgees Publishing Company.

30. Sung C, Fournier J and Chang SY (1949) Systemic infection with Salmonella anatum Report of First Case. Pediatrics 4: 249-253.

31. Investigation Internationale: Belgique, France, RoyaumeUni et le réseau Salm-Net / International investigation: Belgium United Kingdom France and the Salm-Net network. Preliminary report of an international outbreak of Salmonella anatum infection linked to an infant formula milk. (1997) Euro Surveill 2: 190. http://www.eurosurveillance.org/ViewArticle.aspx?ArticleId $=190$. Viewed on 17 February 2009 .

32. Verma JC, Singh BR (2000). Prevalence and distribution of Salmonella serotypes in animals and poultry in India. Current status. Proceedings of Indian Association for Advancement of Veterinary Research, VI Annual Conference, pp. 28-38.

33. Agarwal DS, Bhatia SL, Natarajan R (1970) An outbreak of Salmonella anatum infection in a hospital in Delhi. Indian $\mathrm{J}$ Med Res 58: 20-23.

34. Gaind R (2003) Emerging trends of typhoid fever in India. In: Proceedings of ASM conference on Salmonella: Pathogenesis, epidemiology and vaccine development. University of Sassari, Italy, 20-24 ${ }^{\text {th }}$ September 2003. pp 86

35. Singh BR, Khurana SK, Chauhan M, Gulati BR (2008) Clinical problems of equine patients in India and Antimicrobial drug use. In: Proceedings of $8^{\text {th }}$ Indian Veterinary Congress and XV Annual Conference of IAAVR and National symposium on "Public-Private-Partnership in Veterinary Research and Education Sector, 22-24 February 2008, West Bengal University of Animal and Fishery Sciences, Kolkata, pp. 159-160.

36. Tassios PT, Chadjichristodoulou C, Lambiri M, Kansouzidou-Kanakoudii A, Sarandopoulou Z, KoureaKremastinou J (2000) Molecular typing of multidrug- 
resistant Salmonella blockley outbreak isolates from Greece. Emerg Infect Dis 6: 604.

37. Mammina C, Cannova L, Mass S, Goffredo E, Nastasi A (2002) Drug resistances in Salmonella isolates from animal foods, Italy 1998-2000. Epidemiol Infect 129: 155-161.

38. Singh BR, Jyoti J, Chandra M, Babu N, Sharma G (2009) Drug resistance pattern in Salmonella isolates of equine origin in India. J Infect Develop Ctries 3: 141-147.

\author{
Corresponding author \\ Dr. BR Singh \\ Veterinary Microbiology \\ ICAR Research Complex for NEH Region Nagaland Centre \\ Jharnapani, Medziphema-797 106, Nagaland, India \\ Phone: 0091-3862-247250, Fax: 0091-3862-247241, 0091- \\ $94022830021(\mathrm{M})$ \\ Email: brs1762@yahoo.co.in, brs1762@gmail.com
}

Conflict of interests: No conflict of interests is declared 